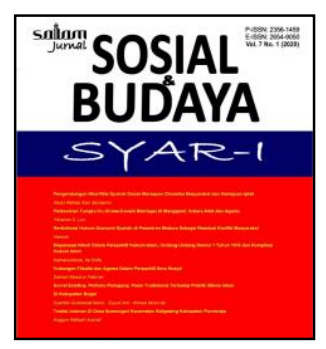

P-ISSN: 2356-1459. E-ISSN: 2654-9050

Vol. 8 No. 3 (2021), pp. 711-734

DOI: 10.15408/sjsbs.v8i3.20347

http://journal.uinjkt.ac.id/index.php/salam/index

\title{
Energi Terbarukan dan Ekonomi Syariah: Sinergitas Mewujudkan Sustainable Development ${ }^{*}$
}

\author{
Azwar Iskandar, ${ }^{1}$ Khaerul Aqbar, ${ }^{2}$ Sulkifili Herman ${ }^{3}$ \\ Sekolah Tinggi Ilmu Islam dan Bahasa Arab (STIBA), Makassar \\ do \\ $10.15408 /$ sjsbs.v8i3.20347
}

\begin{abstract}
The urgency of the availability of renewable energy, green economy and implementation of Sharia Economy actually has a spirit that is in line with the efforts of the global community in supporting sustainable development. The synergy between Sharia Economy practices in Indonesia and renewable energy programs in order to realize it becomes an inevitability. This research aims to describe the concept of synergy of Sharia Economy practices and renewable energy programs in Indonesia in order to realize sustainable development. This research is qualitative descriptive research through library study methods and content analysis. The results showed that the synergy scheme between renewable energy programs and Islamic economic/financial practices can be done in the form of: (i) sharia financial sector can be an instrument of EBT investment financing; (ii) the utilization of EBT may be a supporter and spearhead of halal industry, such as halal food and beverages, Muslim fashion, halal tourism, pharmaceuticals and halal cosmetics and halal media and recreation; and (iii) in the context of socially religious EBT financing, EBT can be done with the concept of ta'äwun and sedekaj jariah through crowd funding and waqf. In order to optimize the synergy between renewable energy programs and sharia economy, some steps and Quick Wins programs that can be done are: (1) campaigns against the excellence of renewable energy to achieve national energy self-sufficiency; (2) create easy access and attractive financing schemes to support renewable energy; (3) conduct research and publication on renewable energy and potential collaboration with other industries in the halal value chain that can be perceived in Indonesia, especially halal tourism.
\end{abstract}

Keywords: renewable, energy, Islamic, economic, sustainable

\begin{abstract}
Abstrak
Urgensi ketersediaan energi terbarukan, green economy dan implementasi Ekonomi Syariah sesungguhnya memiliki ruh yang sejalan dengan upaya masyarakat global dalam mendukung pembangunan berkelanjutan. Sinergitas antara praktik Ekonomi Syariah di Indonesia dan program energi terbarukan dalam rangka mewujudkannya menjadi sebuah keniscayaan. Penelitian ini bertujuan untuk mendeskripsikan konsep sinergitas praktik Ekonomi Syariah dan program energi terbarukan di Indonesia dalam rangka mewujudkan pembangunan yang berkelanjutan (sustainable development). Penelitian ini merupakan penelitian deskriptif kualitatif melalui metode studi pustaka dan content analysis. Hasil penelitian menunjukkan bahwa skema sinergitas di antara program energi terbarukan
\end{abstract}

* Received: May 23, 2021, Revision: May 26, 2021, Published: June 5, 2021.

${ }^{1}$ Azwar Iskandar adalah dosen Sekolah Tinggi Ilmu Islam dan Bahasa Arab (STIBA), Makassar. Email: azwar.iskandar@gmail.com

${ }^{2}$ Khaerul Aqbar adalah dosen Sekolah Tinggi Ilmu Islam dan Bahasa Arab (STIBA), Makassar. Email: khaerul@stiba.ac.id

${ }^{3}$ Sulkifili Herman adalah dosen Sekolah Tinggi Ilmu Islam dan Bahasa Arab (STIBA), Makassar. Email: sulkifliherman@stiba.ac.id 
dan praktik ekonomi/keuangan Syariah dapat dilakukan dalam bentuk: (i) sektor keuangan Syariah dapat menjadi instrumen pembiayaan investasi EBT; (ii) pemanfaatan EBT dapat menjadi pendukung dan ujung tombak industri halal, seperti makanan dan minuman halal, fesyen muslim, pariwisata halal, farmasi dan kosmetik halal dan media dan rekreasi halal; dan (iii) dalam konteks pembiayaan EBT yang bersifat sosial keagamaan, EBT dapat dilakukan dengan konsep ta'āwun dan sedekah jariah melalui urun dana (crowd funding) dan wakaf. Dalam rangka mengoptimalkan sinergitas antara program energi terbarukan dan ekonomi Syariah, beberapa langkah dan program Quick Wins yang dapat dilakukan adalah: (1) kampanye terhadap keunggulan energi terbarukan untuk mencapai swasembada energi nasional; (2) menciptakan kemudahan akses dan skema pembiayaan yang menarik untuk mendukung energi terbarukan; (3) mengadakan riset dan publikasi mengenai energi terbarukan dan potensi kolaborasi dengan industri lain dalam rantai nilai halal yang dapat diaplikasikan di Indonesia, terutama pariwisata halal.

Kata kunci: terbarukan, energi, Islam, ekonomi, sustainable

\section{A. PENDAHULUAN}

Secara global, kebutuhan akan energi dalam kehidupan manusia diprediksi akan terus meningkat. ${ }^{4}$ Hingga akhir tahun 2019, 84 persen kehidupan manusia tergantung pada energi yang berasal dari bahan bakar fosil seperti minyak, gas dan batu bara. Berdasarkan laporan dari Statistical Review of World Energi 2020, diketahui bahwa konsumsi tertinggi energi saat ini masih didominasi oleh minyak (oil) sebesar 193.03 exajoules, natural gas sebesar 141.45 exajoules, batubara (coal) sebesar 157.86 exajoules. Sedangkan, sumber energi lain seperti hidroelektrik, nuklir dan energi terbarukan masih mengambil porsi yang lebih sedikit, masing-masing sebesar 37.66, 24.92, dan 28.98 exajoules. $^{5}$

Tabel 1. Tingkat Konsumsi Energi Dunia Berdasarkan Sumbernya

\begin{tabular}{lrrrr} 
Energy source & $\begin{array}{r}\text { Consumption } \\
\text { (exajoules) }\end{array}$ & $\begin{array}{r}\text { Annual change } \\
\text { (exajoules) }\end{array}$ & $\begin{array}{r}\text { Share } \\
\text { of primary } \\
\text { energy }\end{array}$ & $\begin{array}{r}\text { Percentage point } \\
\text { change in share } \\
\text { from 2018 }\end{array}$ \\
\hline Oil & 193.0 & 1.6 & $33.1 \%$ & $-0.2 \%$ \\
Gas & 141.5 & 2.8 & $24.2 \%$ & $0.2 \%$ \\
Coal & 157.9 & -0.9 & $27.0 \%$ & $-0.5 \%$ \\
Renewables* & 29.0 & 3.2 & $5.0 \%$ & $0.5 \%$ \\
Hydro & 37.6 & 0.3 & $6.4 \%$ & $-0.0 \%$ \\
Nuclear & 24.9 & 0.8 & $4.3 \%$ & $0.1 \%$ \\
\hline Total & $\mathbf{5 8 3 . 9}$ & $\mathbf{7 . 7}$ & & \\
\hline
\end{tabular}

*Renewable power (excluding hydro) plus biofuels

Sumber: Statistical Review of World Energi 2020

4 Juwito, Arif Febriansyah, Sasongko Pramonohadi, and T. Haryono. “Optimalisasi energi terbarukan pada pembangkit tenaga listrik dalam menghadapi desa mandiri energi di Margajaya." Semesta Teknika 15, No. 1 (2015).

BP.PLC., Statistical Review of World Energy 2019,
https://www.bp.com/en/global/corporate/energy-economics/statistical-review-of-world-energy.html. Diakses pada tanggal 31 Maret 2021. 
Data pada Tabel 1 menunjukan bahwa energi terbarukan merupakan sumber energi yang belum dimanfaatkan potensinya secara maksimal untuk menyokong kebutuhan global maupun regional. Sementara konsumsi energi hingga tahun 2040 diprediksi akan terus meningkat. Permintaan energi di seluruh dunia hingga tahun 2040 berkisar pada angka 13.000 Mtoe. Negara yang mendominasi konsumsi energi adalah yang tergabung dalam Organisation for Economic Co-operation and Development (OECD) (Grafik 1). Negara-negara ini mengonsumsi 50 persen rata-rata energi dunia. Secara umum dapat dikatakan bahwa konsumsi tertinggi terdapat di wilayah Asia. Hal ini menjadi sinyal bagi berbagai pihak untuk mengembangkan industri yang medukung energi terbarukan, khususnya di wilayah Asia. ${ }^{6}$

Dalam laporan kajian"Renewable energy Outlook for ASEAN: a Remap Analysis" pada tahun 2016, disebutkan bahwa target energi terbarukan yang diharapkan adalah sebesar 23 persen dari total pasokan energi pada tahun 2025. Untuk dapat mencapai target skenario tersebut, masing-masing negara anggota ASEAN diharapkan dapat mencapai target nasional yang telah ditetapkan. Tantangan yang dihadapi oleh negaranegara di regional ASEAN, termasuk Indonesia adalah bagaimana mengimplementasikan pencapaian target 23 persen tersebut pada tahun $2025 .^{7}$

Indonesia sebagai negara kepulauan, memiliki keunikan karena kaya akan sosio-ekonomi, demografi, politik dan geografis. Hal ini tentu akan sangat berdampak pada agenda pembangunan negara ini. Potensinya terdiri dari 17.000 pulau, adanya sistem demokrasi dan memiliki jumlah penduduk tertinggi ke-4 di dunia. Selain itu, Indonesia adalah negara dengan populasi muslim terbesar di dunia. Ditambah dengan budaya yang kaya, Indonesia negara yang memiliki jati diri dan ciri yang khas dibanding negara-negara lainnya. Perkembangan ekonominya banyak berkontribusi pada penurunan kemiskinan dan menempatkannya masuk ke dalam 10 negara berpenghasilan tertinggi di dunia.

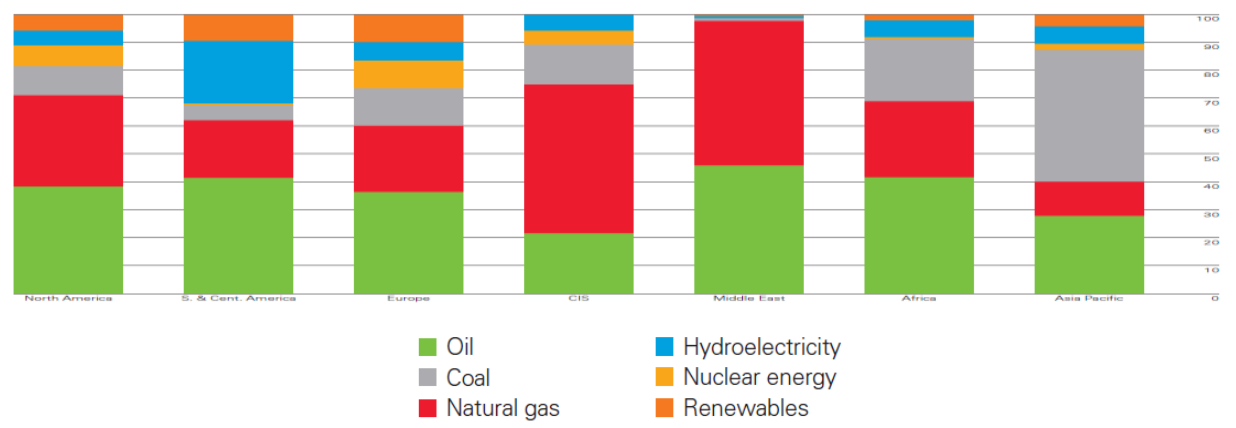

Grafik 1. Pola Konsumsi Energi Berdasarkan Region

Sumber: Statistical Review of World Energi 2020

\footnotetext{
${ }^{6}$ Kementerian Perencanaan Pembangunan Nasional/ Badan Perencanaan Pembangunan Nasional (Bappenas), "Masterplan Ekonomi Syariah Indonesia 2019-2024; Hasil Kajian Analisis Ekonomi Syariah di Indonesia", Cetakan Pertama (2018).

7 The International Renewable Energy Agency (IRENA), “Renewable Energy Outlook For ASEAN”, https://www.irena.org//media/Files/IRENA/Agency/Publication/2016/IRENA REmap_ASEAN_2016_report.pdf. Diakses pada tanggal 31 Maret 2021.
} 
Menurut Kementerian Energi dan Sumber Daya Mineral, energi menjadi kebutuhan dasar dengan per tahun rata-rata pertumbuhannya mencapai 7 persen. Lebih lanjut, 94 persen kebutuhan masih tergantung pada energi fosil. Dengan kondisi saat ini, Indonesia berkontribusi menyumbangkan emisi karbon terbesar dari sektor Land Use, Land Use Change and Forsetry (LULUCF) sebanyak 50 persen. Sektor energi menyumbangkan emisi karbon sebesar 30 persen, dan dari sektor transportasi mencapai 12 persen. Hingga tahun 2050, penggunaan energi di Indonesia diperkirakan akan didominasi oleh kebutuhan pemenuhan listrik pada sektor industri, disusul oleh sektor transportasi dan rumah tangga. Oleh karena itu, pemenuhan kebutuhan energi yang tinggi di masa mendatang mesti diupayakan, di antaranya dengan pemanfaatan dan implementasi energi baru dan terbarukan (EBT) yang ramah lingkungan dalam rangka mewujudkan ketahanan energi nasional. ${ }^{8}$

United Nations Environment Programme (UNEP) mencetuskan gagasan mengenai green economy dalam rangka mendukung upaya pemenuhan kebutuhan energi terbarukan di antaranya melalui penurunan emisi gas rumah kaca. Gagasan tersebut bertujuan memberikan peluang yang besar bagaimana upaya memanfaatkan konsepsi green economy dalam rangka menunjang pelaksanaan pembangunan yang berorientasi pada aspek lingkungan dan ekosistem. UNEP menyatakan bahwa pengertian green economy lebih luas cakupannya dibandingkan Low-Carbon Economy (LCE) atau LowFossil-Fuel Economy (LFFE), yaitu aktivitas ekonomi yang memberikan output minimal terhadap emisi Green Houses Gas (GHG) yang dilepaskan.9 Model ekonomi baru tersebut didasarkan pada ilmu ecological economics yang membahas ketergantungan manusia dan dampak yang ditimbulkan dari aktivitas ekonomi terhadap perubahan iklim dan pemanasan global. Indikator penerapan green economy dalam suatu perekonomian dapat dilihat melalui beberapa aktivitas, seperti peningkatan investasi publik dan private dalam sektor hijau: (i) peningkatan dalam kuantitas dan kualitas lapangan pekerjaan di sektor hijau, (ii) peningkatan GDP dari sektor hijau, (iii) penurunan penggunaan energi/sumber daya per unit produksi, (iv) penurunan level $\mathrm{CO}_{2}$ dan polusi serta (v) penurunan konsumsi yang banyak menghasilkan limbah. ${ }^{10}$

Terkait dengan gagasan konsepsi green economy tersebut, terdapat dua hal yang ingin dicapai. Pertama, ekonomi hijau mencoba untuk membuat konsep ekonomi yang bukan hanya sekedar mempertimbangkan masalah makro ekonomi, khususnya investasi di sektor-sektor yang memproduksi produk ramah lingkungan maupun produksi barang dan jasa yang lebih ramah lingkungan (green investment), namun juga difokuskan pada bagaimana kontribusi investasi hijau tersebut terhadap pertumbuhan lapangan pekerjaan di bidang yang terkait dengan ramah lingkungan (green job). Kedua, green economy mencoba untuk menyiapkan panduan pro-poor green investment, atau investasi hijau yang mampu mendorong pengentasan masalah kemiskinan.

8 Azhar, Muhamad, dan Dendy Adam Satriawan. "Implementasi Kebijakan Energi Baru dan Energi Terbarukan Dalam Rangka Ketahanan Energi Nasional." Administrative Law and Governance Journal 1, no. 4 (2018): 398-412.

9 UNEP, “Environmental Management Accounting Procedures E Principles", Newyork (2011).

${ }^{10}$ Ika Yunia Fauzia, “Urgensi Implementasi Green Economy Perspektif Pendekatan Dharuriyah Dalam Maqashid Al-Shariah"Jurnal Ekonomi dan Bisnis Islam 2, no. 1 (2016). 
Tujuan utamanya adalah untuk mendorong agar para pembuat kebijakan mampu membuat semua jajaran pemerintahan dan sektor swasta ikut serta untuk mendukung peningkatan investasi hijau. ${ }^{11}$ Model ekonomi ini diciptakan akibat adanya kecenderungan manusia yang lebih pada profit oriented dibandingkan sustainable oriented. Model ekonomi yang ada saat ini, mendorong manusia untuk menggunakan segala cara tanpa memperhatikan pelestarian lingkungan untuk mendapatkan keuntungan yang maksimum.

Pemanfaatan dan eksploitasi sumber daya alam yang tidak diimbangi oleh upaya konservasi yang mengatasnamakan kesejahteraan hidup manusia tampaknya mulai menampilkan dampak negatif terhadap keberlangsungan lingkungan hidup. Hal ini tidak hanya mengancam keberlangsungan lingkungan alam, tetapi juga keberlangsungan hidup manusia itu sendiri. Isu keterbatasan energi, pemanasan global dan perubahan iklim hanyalah sebagian dari sekian banyak isu lingkungan yang demikian pelik untuk diperhatikan yang tidak hanya bersifat lokal tetapi juga global. Meningkatnya kesadaran terhadap isu lingkungan ini mendorong negaranegara di dunia, termasuk Indonesia, untuk memikirkan upaya pengimbangan laju ekonomi dengan upaya konservasi lingkungan alam dan melahirkan paradigma ekonomi yang memasukkan aspek lingkungan dan keadilan sosial ke dalamnya. ${ }^{12} \mathrm{Di}$ Indonesia, konsep pembangunan berkelanjutan sudah dimulai sejak tahun 1970-an, namun hingga sekarang masih cenderung fokus pada pembangunan ekonomi, bahkan pada pertumbuhan yang cenderung pendek. Model pembangunan yang dikembangkan hanya menggerakkan pembangunan ekonomi yang cenderung ekstraktif. Tanpa menafikan adanya perbaikan kualitas seumber daya dan lingkungan, namun secara umum dapat dikatakan bahwa upaya mempertahankan fungsi lingkungan dan pemnafaatan saumber daya alamsecara lestari masih jauh dari yang diharapkan. ${ }^{13}$

Konsep implementasi green economy diyakini mampu menjadi solusi bagi permasalahan tersebut di atas dan membawa kehidupan dan peradaban global menjadi lebih baik, berkeadilan, sejahtera, dan berkesinambungan. Hal ini sesungguhnya sesuai dengan value dalam prinsip atau konsep Ekonomi Syariah khususnya pada sudut pandang maqāșid al-syarī'ah. Secara terminologi, Maqāshid alsyarīah adalah maksud Allah selaku pembuat syariat untuk memberikan kemaslahatan (maslahah) kepada manusia, yaitu dengan terpenuhinya kebutuhankebutuhan darüriyyah (primer), häjiyyah (sekunder), dan tahsiniyyah (tersier) agar manusia bisa hidup dalam kebaikan dan dapat menjadi hamba Allah yang baik. ${ }^{14}$ Khusus untuk kategori darüriyyah, para ulama kemudian membaginya lebih rinci menjadi al-kulliyāt al-khamsah yaitu hifzu al-dīn (penjagaan agama), hifzu al-nafs

${ }^{11}$ Azwar Iskandar dan Khaerul Aqbar. "Green Economy Indonesia Dalam Perspektif Maqashid Syari'ah." Al-Mashrafiyah: Jurnal Ekonomi, Keuangan, dan Perbankan Syariah 3, no. 2 (2019): 83-94.

12 Idem.

13 Makmun, Makmun. "Green Economy: Konsep, Impelentasi dan Peran Kementerian Keuangan." Jurnal Ekonomi dan Pembangunan 19, no. 2 (2011): 1-15.

${ }^{14}$ Ika Yunia Fauzia. "Urgensi Implementasi Green Economy Perspektif Pendekatan Dharuriyah Dalam Maqashid Al-Shariah." Jurnal Ekonomi dan Bisnis Islam (JEBIS) 2, no. 1 (2016): 87-104. 
(penjagaan jiwa), hifzu al-aql (penjagaan akal), hifzu al-nasl (penjagaan keturunan), dan hifzu al-māl (penjagaan harta benda). Darūriyyah adalah suatu kondisi di mana ketika manusia tidak bisa mendapatkan kebutuhannya, maka manusia akan rusak dan tidak sejahtera. Hal ini berbeda dengan häjiyyah dan tahsiniyyah, di mana häjiyyah adalah kondisi di mana seseorang ketika tidak mendapatkan kebutuhannya, maka tidak akan mengancam kehidupannya. Tahsiniyyah adalah pemenuhan kebutuhan yang konteknya hanya untuk mempermudah dan menambah nilai hidup manusia. Para ulama terdahulu menyepakati bahwa syariat diturunkan untuk membangun kemaslahatan manusia di dunia dan akhirat. Syariat diturunkan untuk dilaksanakan sesuai dengan maqāṣid-nya agar kehidupan yang adil dapat ditegakkan dan kesejahteraan sosial dapat diwujudkan.

Berdasarkan deskripsi terkait urgensi ketersediaan energi terbarukan, green economy dan implementasi ekonomi Syariah yang sesungguhnya memiliki ruh yang sejalan dengan upaya masyarakat global dalam mendukung program energi tersebut, penulis tertarik untuk melihat lebih jauh bagaimana sinergitas antara praktik ekonomi Syariah di Indonesia dan program energi terbarukan dalam rangka mewujudkan pembangunan yang berkelanjutan (sustainable development). Oleh karena itu, penelitian ini bertujuan untuk mendeskripsikan konsep sinergitas praktik ekonomi Syariah dan program energi terbarukan di Indonesia dalam rangka mewujudkan pembangunan yang berkelanjutan (sustainable development).

\section{KERANGKA TEORI}

\section{Kebijakan Nasional Terkait Energi Terbarukan}

Isu dan permasalahan energi nasional saat ini telah dituangkan dalam Peraturan Presiden Republik Indonesia Nomor 22 Tahun 2017 Tentang Rencana Umum Energi Nasional (RUEN). ${ }^{15}$ Peraturan ini menjadi dasar pemerintah dalam melakukan pemodelan kebutuhan pasokan energi sampai dengan tahun 2050. Pokok permasalahannya adalah sebagai berikut: (1) sumber daya energi masih diperlakukan sebagai komoditas yang menjadi sumber devisa negara, belum sebagai modal pembangunan; (2) penurunan produksi dan gejolak harga minyak bumi; (3) akses dan infrastruktur energi yang terbatas; (4) ketergantungan terhadap Impor BBM dan LPG; (5) harga EBT belum kompetitif dan subsudi energi belum tepat sasaran; (6) pemanfaatan energi belum efisien; (7) penelitian, pengembangan dan penguasaan ilmu pengetahuan dan teknologi masih terbatas; (8) kondisi geopolitik dunia dan isu lingkungan global; dan (9) cdangan penyangga energi belum tersedia.

Secara khusus, di bidang kemandirian energi pada pemerintah Indonesia, sasaran kemandirian energi tahun 2020 dilakukan antara lain untuk memenuhi rasio elektrifikasi mendekati 100 persen dan peningkatan produksi sumber daya energi dari sumber baru dan terbarukan. Di sisi distribusi energi terutama gas bumi, penekanan

\footnotetext{
${ }^{15 N g a d a . O r g . \quad D a t a b a s e} \quad$ Peraturan. https://ngada.org/ps222017.htm\#: :text=1.Rencana\%20Umum\%20Energi\%20Nasional,mencapai\%20sasaran\%20Kebijakan\%20Ene rgi\%20Nasional, diakses pada tanggal 21 April 2021.
} 
dilakukan untuk pembangunan ruas pipa transmisi dan jaringan pipa distribusi gas sepanjang $12.597 \mathrm{~km}$, SPBG sebanyak 2 unit (APBN), serta jaringan gas kota di 12 lokasi. Asas pengembangan energi nasional mengacu pada prinsip Kebijakan Energi Nasional (KEN) yang berkeadilan, berkelanjutan, dan berwawasan lingkungan. Tujuannya untuk menciptakan kemandirian dan ketahanan energi nasional. Dorongan pemerintah dalam mencapai kemandirian energi di Indonesia dilakukan dengan peningkatan EBT yang saat ini telah dituangkan dalam:

a. Perpres Nomor 2 tahun 2017 tentang RUEN (Rencana Umum Energi Nasional)

b. Peraturan Kemenkeu tentang skema pembiayaan Kemitraan PemerintahSwasta yang menyediakan fasilitas termasuk Dana Pengembangan Proyek (PDF), Viability Gap Fund (VGF), Pembayaran Ketersediaan (AP) dan jaminan Pemerintah untuk proyek-proyek infrastruktur. PMK No. 223 / PMK.011 / 2012; PMK No.190 / PMK.08 / 2015 dan PMK No. 95 / PMK.08 / 2017.

c. Peraturan Menteri Energi dan Sumber Daya Mineral - Peraturan Menteri ESDM No. 50/2017 tentang Pemanfaatan energi terbarukan dalam pembangkit listrik.

d. Peraturan Menteri ESDM No.38 / 2016 tentang Percepatan pelistrikan pedesaan di pelosok, perbatasan dan pulau-pulau kecil berpenghuni melalui bisnis pasokan listrik skala kecil.

e. Peraturan Pemerintah PP No.23 / 2014 sebelumnya PP No.14 / 2012 tentang Bisnis Kelistrikan yang memungkinkan perusahaan swasta untuk berpartisipasi.

f. Peraturan Menteri ESDM Nomor 35/2014 tentang Pembentukan "Pelayanan Satu Pintu" tentang penerbitan izin untuk sektor listrik.

g. Peraturan Pemerintah PP No. 79 /2014 tentang Kebijakan Energi Nasional.

h. Peraturan Menteri Keuangan (Peraturan Menteri Keuangan) PMK No. 21/ PMK.011/2010 tentang Pemberian fasilitas perpajakan dan bea cukai untuk kegiatan menggunakan energi terbarukan sumber.

i. Revisi Undang-Undang No. 30 Tahun 2009 tentang Ketenagalistrikan agar swasta mendapat kesempatan untuk membantu kemandirian dalam penyediaan tenaga listrik dan peraturan pelaksanaan yang berkaitan peraturan di bidang Energi Baru dan Energi Terbarukan (EBT).

j. $\quad$ Undang-Undang No.30 Tahun 2007 tentang Energi

\section{Energi Terbarukan dalam Konsep Islam dan Ekonomi Syariah}

Al-Qur'an adalah pedoman lengkap yang mencakup semua aspek kehidupan, baik spiritual, intelektual, politik, sosial, ekonomi maupun energi. Al-Qur'an adalah kitab yang berisi tinjauan tentang konsep energi atau sumber-sumber energi terbarukan yang secara konseptual dan sederhana telah diilustrasikan dalam beberapa 
ayat Al-Qur'an. ${ }^{16}$ Sumber-sumber energi dan energi terbarukan banyak disebutkan dalam Al-Qur'an. Beberapa ayat Al-Qur'an yang menjelaskan berbagai sumber energi dan energi terbarukan disebutkan oleh Hasanuz Zaman ${ }^{17}$ dan Aan Jaelani ${ }^{18}$, yaitu sebagai ditunjukkan pada Tabel 2 berikut.

Tabel 2. Al-Qur'an dan Konsep Energi

\begin{tabular}{|c|c|c|}
\hline No. & $\begin{array}{l}\text { Nama Surah dan Ayat Al- } \\
\text { Qur'an }\end{array}$ & Isu Terkait energi \\
\hline 1. & Al-An'ām, 6: 95 & $\begin{array}{l}\text { Butir tumbuh-tumbuhan dan biji buah- } \\
\text { buahan }\end{array}$ \\
\hline 2. & Al-Hijr, 15: 22 & $\begin{array}{l}\text { Angin, perkawinan tanaman, hujan, dan } \\
\text { air untuk minum }\end{array}$ \\
\hline 3. & Al-Nahl, 16: 11-13 & $\begin{array}{l}\text { Air hujan, tanaman yang tumbuh, malam } \\
\text { dan siang, matahari dan bulan, bintang, } \\
\text { bumi untuk dikelola manusia }\end{array}$ \\
\hline 4. & Yasin, 36: 34 & Kebun kurma dan anggur, dan mata air \\
\hline 5. & Al-Hajj, 22: 65 & $\begin{array}{l}\text { Bumi dan bahtera yang berlayar di } \\
\text { lautan; menahan benda langit jatuh ke } \\
\text { bumi. }\end{array}$ \\
\hline 6. & Al-Mu'minūn, 23: 21-22 & $\begin{array}{l}\text { Binatang ternak, air susu, konsumsi, } \\
\text { binatang dan perahu untuk transportasi. }\end{array}$ \\
\hline 7. & Al-Rūm, 30: 46 & $\begin{array}{l}\text { Angin sebagai pembawa berita gembira, } \\
\text { kapal berlayar untuk mencari } \\
\text { penghidupan }\end{array}$ \\
\hline 8. & Al-Fāțir, 35: 12 & $\begin{array}{l}\text { Laut tawar dan asin yang menghasilkan } \\
\text { daging segar dan perhiasan, dan kapal } \\
\text { yang berlayar. }\end{array}$ \\
\hline 9. & Saba', 34: 10 & Besi, baju zirah \\
\hline 10. & Saba', 34: 12 & Angin dan transportasi \\
\hline 11. & Al-Hadīd, 57: 25 & Besi dan pemanfaatannya \\
\hline
\end{tabular}

16 Jaelani, Aan. "Renewable Energi Policy in Indonesia: Scientific signs of the Qur'an and Implementation in Islamic Economic." MPRA Paper 83314 (2017).

17 Hasan-uz-Zaman, Syed Muhammad. Economic Guidelines in the Quran. Vol. 21. International Institute of Islamic Thought (IIIT), 1999.

18 Aan Jaelani. "Renewable Energi Policy in Indonesia: Scientific signs of the Qur'an and Implementation in Islamic Economic.” MPRA Paper 83314 (2017). 
Pada Tabel 2 di atas, Allah menciptakan sumber energi untuk manusia dengan cara menundukkan alam dan isinya. Secara ilmiah, soul, water dan vegetation melalui suatu proses yang didahului dengan adanya sumber energi yang berasal dari air hujan. ${ }^{19}$ Air ini dapat menyuburkan tanah dan menumbuhkan tanam-tanaman (seperti kurma dan anggur) yang sebagiannya melalui perantaraan angin sehingga beberapa tumbuhan tertentu mengalami penyerbukan. ${ }^{20}$ Sumber energi yang lainnya berupa mata air yang dimanfaatkan oleh manusia dalam kehidupannya. Isyarat ilmiah pada beberapa ayat di atas antara lain berpa sumber energi nabati yang berasal dari tumbuhan dapat dimanfaatkan untuk sumber energi terbarukan sebagai pengganti bahan bakar. Oleh karena itu, sumber energi terbarukan adalah sumber energi ramah lingkungan yang tidak mencemari lingkungan dan tidak memberikan kontribusi terhadap perubahan iklim dan pemanasan global, karena energi yang didapatkan berasal dari proses alam yang berkelanjutan, seperti sinar matahari, angin, air, biofuel, dan geothermal. Ini menegaskan bahwa sumber energi telah tersedia di Indonesia, tidak merugikan lingkungan, dan menjadi alasan utama EBT ini sangat terkait dengan masalah lingkungan dan ekologi. ${ }^{21}$

Dalam ekonomi Islam, pendekatan filosofis tentang energi dari perspektif AlQur'an dapat ditelusuri dari tiga aspek yang saling berkaitan dalam ekonomi energi, yaitu tugas manusia sebagai khalifah Allah dalam memakmurkan bumi, lingkungan sebagai tempat hidup manusia, dan kebutuhan manusia terhadap energi. Dalam AlQur'an, manusia merupakan makhluk yang paling potensial sehingga Allah mendelegasikan tugas utama sebagai khalifah kepada manusia (Q.S. al-Baqarah, 2: 2932) untuk mengelola dan memakmurkan bumi (Q.S. Hud, 11: 61-62). Manusia diberikan potensi akal yang mampu menciptakan teknologi untuk mengelola bumi dan sumber daya alam, sebagaimana Allah telah menciptakan langit, bumi, gunung, air, dan tumbuhan (Q.S. al-Anbiya', 21: 30-31), sehingga manusia dapat menikmati seluruh karunia tersebut untuk memenuhi kebutuhan hidup dan melangsungkan kehidupannya, termasuk kebutuhan energi.

Begitu juga, Al-Qur'an telah menerangkan dalam surah al-Rum ayat 41 sampai 42, surah al-Qashash ayat 77, dan surah al-A'raaf ayat 56 dimana pada ayat-ayat tersebut diterangkan bahwa Allah menciptakan alam semesta dan segala isinya adalah untuk dimanfaatkan oleh manusia demi kesejahteraan hidup dan kemakmurannya. Manusia diangkat sebagai khalifah di bumi agar dapat menjaga kelestarian alam dan jangan sampai rusak. Manusia diperbolehkan menggali kekayaan alam, mengolahnya, dan memanfaatkan sebagi bekal beribadah kepada Allah dan beramal saleh. ${ }^{22}$ Oleh karenanya, semua yang diciptakan oleh Allah menjadi bagian dari kebutuhan hidup manusia, namun manusia diberikan tanggung jawab

\footnotetext{
${ }^{19}$ Badr al-Din Muhammad Al-Zarkasyi, Al-burhan fi 'ulum Al-Qur'an. Kairo: Dar al-Turath, 1984.

${ }^{20}$ Ramli, Saipolbarin, Sumaiya Zainal Abidin Murad, and Ahmad Fikri Hj Husin. "Biodiesel in holy Quran: among the review of the Arabic lexicography and modern science." Mediterranean Journal of Social Sciences 5, no. 19 (2014): 336-336.

${ }^{21}$ Suprayogi, M. , Jurnal Energi 2. Jakarta: Kementerian ESDM, 2016.

${ }^{22}$ Aziz, R. M. "Penanganan Energi Pada Krisis Ekonomi Akibat Covid-19 Sesuai Agama dan Sains." In Seminar Nasional Teknologi Industri Hijau, vol. 2, no. 1, pp. 194-204. 2020.
} 
sebagai kewajiban agama untuk mengelola dengan baik, tidak berbuat kerusakan di bumi dengan melakukan eksploitasi yang merugikan manusia dan lingkungan (Q.S. Al-Qashash, 22: 77), dan bertindak efisien dalam pemanfaatan sumberenergi (Q.S. alAn'am, 6: 141). ${ }^{23}$ Dengan kata lain, tugas manusia dalam memakmurkan bumi merupakan kewajiban agama, ${ }^{24}$ termasuk pemanfaatan energi untuk kesejahteraan manusia dan mengembangkan energi terbarukan. ${ }^{25}$

Vaghefi et al. ${ }^{26}$ menyatakan bahwa pandangan Islam tentang sumber daya alam bersumber pada Al-Qur'an. Dalam Al-Qur'an disebutkan beberapa prinsip penting tentang konservasi lingkungan, serta menilai kerusakan lingkungan dan kekeliruan dalam pengelolaan sumber daya alam sebagai perbuatan jahat (Q.S. Al-A'raf, 7:31; AlAn'am, 6: 141). Dengan demikian, konservasi energi dari penyalahgunaan dan eksploitasi melalui penghematan energi termasuk kewajiban agama.

Demikian pula pengembangan sumber energi terbarukan yang dibutuhkan masyarakat, secara maqāṣid syarī'ah (tujuan-tujuan syari'ah) pada aspek pemeliharaan nyawa manusia, maka pengembangan energi terbarukan yang bertujuan untuk kelangsungan hidup manusia, kebutuhan terhadap konsumsi energi, kesejahteraan masyarakat, dan menghindari krisis energi, maka pengembangan energi terbarukan bersifat wajib secara agama. ${ }^{27}$ Dalam konteks EBT, Rasulullah saw. bersabda bahwa "manusia berserikat dalam tiga hal yaitu air, padang rumput gembalaan dan api". Dalam konteks kekinian, hadis tersebut menuntun kita agar secara bersama-sama menjaga air, makanan dan energi. Konteks tersebut sangat selaras dengan konsep pembangunan berkelanjutan (sustainable development) guna menghadapi peningkatan populasi dunia, urbanisasi, serta perubahan pola makan dan pertumbuhan ekonomi. ${ }^{28}$

Kerusakan lingkungan hidup adalah karena konsep ekonomi kapilatistik yang ribawi dengan konsep "time value of money", yaitu uang diterima saat ini lebih berharga daripada uang yang diterima masa datang. Konsep ini mengakibatkan kegiatan ekonomi yang ekstraktif, dimana seluruh sumberdaya alam harus secepatnya dieksploitasi untuk mendapatkan keuntungan sebesar-besarnya secepatnya. Hal ini tentu menimbulkan kerusakan lingkungan yang hebat karena alam memiliki daya dukung dan daya tampung tertentu. Di lain pihak produktivitas dan kesinambungan ekonomi sangat bergantung pada kesinambungan interaksi timbal balik antara manusia dan jasa ekosistem yang seimbang. Oleh karena itu, konsep keuangan berkelanjutan yang diterapkan Otoritas Jasa Keuangan (OJK) yang mewajibkan

${ }^{23}$ Ibn Hayyan, M. “Tafsir al-bahr al-muhit.” Beirut: Dar al-Kutub al-'Ilmiyyat (1993).

${ }^{24}$ Aan Jaelani. "Kebijakan Energi Baru Terbarukan di Indonesia: Isyarat Ilmiah Al-Qur'an dan Implementasinya dalam Ekonomi Islam." MPRA (83314) (2017).

${ }^{25}$ Mardliyah, Watsiqotul, S. Sunardi, and Leo Agung. "Peran Manusia Sebagai Khalifah Allah di Muka Bumi: Perspektif Ekologis dalam Ajaran Islam." Jurnal Penelitian 12, no. 2 (2018): 355-378.

${ }^{26}$ Vaghefi, Negin, Chamhuri Siwar, and Sarah Aziz Abdul Ghani Aziz. "Green economy: issues, approach and challenges in muslim countries." Theoretical Economics Letters 5, no. 01 (2015): 28.

27 Aan Jaelani. "Public financial management in Indonesia: Review of Islamic public finance." MPRA Paper 72340 (2015).

${ }^{28}$ MUI-LPLHSDA, Pembangunan dan Pembiayaan Syariah Energi Baru Dan Terbarukan Untuk Rumah Ibadah, https://mui-lplhsda.org/pembangunan-dan-pembiayaan-syariah-energi-baru-dan-terbarukanuntuk-rumah-ibadah/, diakses pada tanggal 4 April 2021. 
seluruh perusahaan untuk mengalokasikan biaya dampak lingkungan ${ }^{29}$ sangatlah tepat, karena inti dari ekonomi adalah untuk memenuhi kebutuhan hidup manusia yang tergantung dari terjaganya fungsi jasa ekosistem yang seimbang. Allah telah memerintahkan kita untuk menjaga bumi dalam mencari rezeki kita, seperti firmanNya dalam Surah al-Baqarah ayat 60, "Makan dan minumlah rezki (yang diberikan) Allah, dan janganlah kamu berkeliaran di muka bumi dengan berbuat kerusakan."

\section{B. METODE PENELITIAN}

Berdasarkan tujuan yang hendak dicapai, penelitian ini termasuk ke dalam kategori/jenis penelitian deskriptif yang bertujuan untuk menggambarkan situasi atau gejala tertentu secara terperinci. ${ }^{30}$ Dari sisi pendekatan, penelitian ini menggunakan pendekatan kualitatif melalui metode studi pustaka dan content analysis. ${ }^{31}$ Metode studi/riset kepustakaan (library research) pada penelitian ini menggunakan sumber data yang diperoleh dari hasil penelitian, peraturan, artikel dan buku-buku referensi yang membahas topik yang berkaitan dengan tema penelitian. ${ }^{32}$ Sedangkan metode content analysis merupakan metode yang digunakan untuk mengetahui simpulan dari sebuah teks. Atau dengan kata lain, analisis isi dalam penelitin ini ingin mengungkap gagasan penulis yang termanifestasi maupun yang laten. ${ }^{33}$ Sumber data yang digunakan berupa data sekunder yang diperoleh dari hasil penelitian, artikel dan buku-buku referensi yang membahas topik yang sama, khususnya pada dokumen Master Plan Ekonomi Syariah Indonesia. Pengumpulan data dalam penelitian ini menggunakan teknik dokumentasi, pencarian data atau teori yang relevan dengan pertanyaan penelitian Data yang diperoleh berupa bahan pustaka kemudian diolah dan dianalisis secara kritis dan mendalam untuk mendukung proposisi dan gagasan yang ada dari berbagai referensi. ${ }^{34}$

\section{HASIL TEMUAN DAN PEMBAHASAN}

\section{Sinergitas Program EBT dan Ekonomi Syariah}

Rantai nilai energi terbarukan dimulai dari kesediaan sumber daya alam sampai dengan pemanfaatan akhir dari energi itu sendiri. Pemanfaatannya untuk berbagai sektor, seperti kebutuhan rumah tangga, transportasi, industri, dan komersial. Terdapat juga industri primer yaitu terdiri dari hulu (mengangkat dari sumber asalnya) dan hilir (mengolah menjadi produk energi). Dalam

${ }_{29}$ Peraturan Otoritas Jasa Keuangan No. 51/POJK.03/2017 tanggal 18 Juli 2017 tentang Penerapan Keuangan Berkelanjutan

${ }^{30}$ M. Hamdi dan Ismaryati S, Materi Pokok Metodologi Penelitian Administrasi; 1-12; MAPU5103/4 SKS, (Tangerang Selatan: Universitas Terbuka, 2019).

${ }^{31}$ Sarwono Jonathan. Metode penelitian kuantitatif dan kualitatif, (Graha Ilmu, 2006).

32John W. Creswell. "Research Design: Pendekatan Kualitatif, Kuantitatif dan Mixed, terj." Achmad Fawaid. Yogyakarta: Pustaka Pelajar (2012).

${ }^{33}$ Margrit Schreier. Qualitative content analysis in practice. Sage publications, 2012.

${ }^{34}$ Sri Haryanto. "Pendekatan Historis Dalam Studi Islam." Manarul Qur'an: Jurnal Ilmiah Studi Islam 17, no. 1 (2017): 127-135. 
pengembangannya, industri energi terbarukan dapat menjadi peluang sekaligus tantangan. Fokusnya pada aspek pasar, Sumber Daya Manusia (SDM), teknologi, regulasi, pembiayaan dan research $\mathcal{E}$ development $(\mathrm{R} \& \mathrm{D})$.

Keunggulan Indonesia adalah memiliki sumber daya yang melimpah dalam mengimplementasikan energi terbarukan yang dapat disediakan secara lokal. Berbagai kebijakan di skala regional dan nasional yang ada menjadi aspek pendukung. Selain itu, potensi ketersediaan sumber energi terbarukan di Indonesia beragam dan cukup besar yang telah didukung oleh teknologi untuk pengembangan energi terbarukan yang relatif mudah dipelajari untuk diimplementasikan. Meski pada dasarnya sudah memiliki keunggulan dan aspek pendukung, pengembangan energi terbarukan di Indonesia masih belum optimal. Salah satu penyebabnya adalah pengembangan energi terbarukan memerlukan biaya investasi yang tinggi dan harga jual produk belum kompetitif. Distribusi energi terbarukan masih memiliki akses pasar yang terbatas dan belum dapat diproduksi secara massal. Selain itu, saat ini pengembangan energi terbarukan belum didukung oleh infrastruktur yang memadai. Hal lain yang perlu menjadi perhatian adalah belum adanya sinergi efektif dari para pemangku kebijakan untuk mengeksekusi potensi pengembangan energi terbarukan yang dimiliki oleh Indonesia.

Padahal sejatinya, dengan pengembangan energi terbarukan, ketergantungan akan energi fosil dapat berkurang. Sektor ini berpotensi untuk menyerap banyak tenaga kerja yang dapat menurunkan tingkat pengangguran. Pengembangan energi terbarukan ini berpotensi untuk dapat meningkatkan nilai tambah dari sumber energi dan membuka kesempatan perluasan skala usaha. Dari segi otonomi daerah, energi terbarukan membuka peluang daerah untuk memiliki otonomi sumber energi.

Dalam rangka untuk mendukung tercapainya visi Indonesia yang mandiri, makmur dan madani dengan menjadi pusat ekonomi dan keuangan Syariah terkemuka dunia, klaster energi terbarukan dapat menjadi katalisator untuk penguatan halal rantai nilai (halal value chains). ${ }^{35}$ Kontribusinya terlihat dalam peningkatan kemandirian ekonomi melalui swasembada energi. Skema sinergitas di antara program energi terbarukan dan ekonomi/keuangan Syariah sebagiamana ditunjukkan pada Gambar 1. Sebagai titik awal sinergi, sektor keuangan Syariah dapat menjadi salah satu solusi bagi permasalahan minimnya ketersediaan instrumen pembiayaan yang sesuai dengan kebutuhan investasi EBT. Melalui berbagai pembiayaan berbasis syariah dengan berbagai skema, ekosistem industri keuangan Syariah dapat berkontribusi menjadi salah satu faktor pendukung pencapaian target EBT yang telah ditetapkan untuk tahun 2025 dan 2050.

Dalam mengembangkan investasi energi terbarukan, pemerintah dan swasta membagi porsinya dalam investasi. Sumber-sumber pendanaan energi terbarukan di Indonesia meliputi kementerian dan Perusahaan Listrik Negara (PLN), Anggaran Pendapatan dan Belanja Daerah (APBD), hibah, dan obligasi hijau (green sukuk).

35 Kementerian Perencanaan Pembangunan Nasional/ Badan Perencanaan Pembangunan Nasional (Bappenas). "Masterplan Ekonomi Syariah Indonesia 2019-2024; Hasil Kajian Analisis Ekonomi Syariah di Indonesia," Cetakan Pertama (2018). 
Hingga tahun 2018 pendanaan untuk EBT disalurkan melalui Kementerian Energi Sumber Daya Meneral (ESDM) dan PLN. Skema pendanaan lainnya adalah melalui KPBU (kerja sama pemerintah dan badan usaha) dengan independent power producer. Investasi melalui skema APBD (dana alokasi khusus/DAK) dan Investasi oleh kementerian lain. Dana hibah sebagai salah satu sumber pendanaan non-APBN, dilakukan memalui skema pendanaan lainnya yang diperoleh dari hibah luar negeri seperti MCA-Indonesia, Green Climate Fund, ESP3, USAID-ICED, dan lainnya. Keperluan pendanaan yang cukup tinggi untuk pengembangan energi terbarukan menjadi potensi bagi keuangan Syariah untuk dapat berkontribusi melalui produkproduk keuangannya. Salah satu pilihan instrumen keuangan syariah yang dapat dimanfaatkan adalah sukuk. Proyek yang berkaitan dengan sustainable energy and development dapat didanai oleh sukuk. Hal itu meliputi energi bersih, transportasi massal, konservasi air, kehutanan, dan teknologi rendah karbon. Sukuk merupakan istilah baru yang dikenalkan sebagai pengganti kata obligasi syariah (islamic bonds). Secara terminologi, sukuk merupakan bentuk jamak dari kata "sakk" dalam bahasa Arab yang berarti sertifikat atau bukti kepemilikan. Sukuk mulai dikenal pada tahun 2002 di Indonesia dengan diterbitkannya sukuk korporasi oleh Indosat dengan nilai Rp 300 miliar menggunakan akad muḍārabah.

Setelah momentum tersebut, pemerintah Indonesia melalui Kementerian Keuangan mengeluarkan sukuk negara sebagai instrumen untuk membiayai infrastruktur. Selama sepuluh tahun sejak debutnya, pemerintah saat ini telah rutin menerbitkan sukuk negara baik di level nasional maupun internasional. Beberapa seri yang telah terbit di pasar adalah sukuk ritel, sukuk negara internasional (SNI), dan sukuk dana haji. ${ }^{36}$ Perkembangan pesat pada inovasi jenis instrumen juga terjadi pada penerbitan sukuk negara setelah tahun 2010. Di tahun 2012, pemerintah melakukan lelang reguler sukuk negara seri PBS dan SPN-S, lelang sukuk negara tambahan (green shoe option), dan SNI dengan format Islamic GMTN. Selanjutnya pada tahun 2013, pemerintah pertama kalinya mulai menerbitkan sukuk berbasis proyek dengan nama project based sukuk (PBS). Satu tahun setelahnya, pemerintah menerbitkan sukuk global kelima dan keenam diterbitkan pada periode 2014-2015. Tahun 2016, sukuk negara ritel SR-008 diterbitkan oleh pemerintah dan dilanjutkan dengan menerbitkan Sukuk ritel SR-009 di tahun 2017.37

Pada tahun 2018, pemerintah pertama kalinya menerbitkan green sukuk sebagai kontribusi dalam Sustainable Development Goals (SDGs). Sukuk jenis ini diterbitkan oleh pemerintah Indonesia untuk membantu pendanaan perubahan iklim. ${ }^{38}$ Pemerintah menerbitkan green sukuk pertama kali di pasar global tahun 2018 dengan total sebesar USD1,25 milyar dengan underlying berupa proyek-proyek hijau di kementerian /lembaga. Indonesia tercatat menjadi Negara pertama yang menerbitkan Sovereign

36 Kementerian Keuangan, “Ekonomi Hijau Untuk Masa Depan Peradaban." Majalah Media Keuangan XIV, no. 163 (2021).

37 Idem.

38 Eri Hariyanto, Green Financing, Sukuk Negara Dan Pembangunan Berkelanjutan, https://www.djppr.kemenkeu.go.id/page/load/2269/green-financing-sukuk-negara-dan-pembangunanberkelanjutan, diakses pada tanggal 21 April 2021. 
Green Sukuk dan Sovereign Retail Green Sukuk di dunia. Penerbitan green sukuk ini mendapatkan 10 penghargaan internasional antara lain dari IFR Asia, Islamic Finance News, Finance Asia, Euromoney, The Triple A, dan Climate Bond Initiative. Reputasi sangat baik diperoleh Indonesia atas penerbitan Green Sukuk ini. ${ }^{39}$ Indikasi menguatnya peran sukuk negara dalam pembiayaan APBN di antaranya dapat dilihat dari peningkatan jumlah penerbitan sukuk negara dari tahun ke tahun. Berdasarkan data Direktorat Pembiayaan Syariah Direktorat Jenderal Pengelolaan Pembiayaan dan Risiko (DJPPR), penerbitan sukuk negara mengalami peningkatan yang sangat signifikan dari pertama diterbitkan tahun 2008 yang hanya sebesar $\operatorname{Rp} 4,7$ triliun hingga penerbitan pada tahun 2018 yang mencapai Rp 192,49 triliun. Setelah penerbitan green sukuk pada 22 Februari 2018 bertenor lima tahun senilai USD 1,75 miliar dan didaftarkan pada bursa Singapura dan NASDAQ Dubai, akumulasi total penerbitan sukuk negara sejak tahun 2008-2018 mencapai Rp 950.26 trilun.

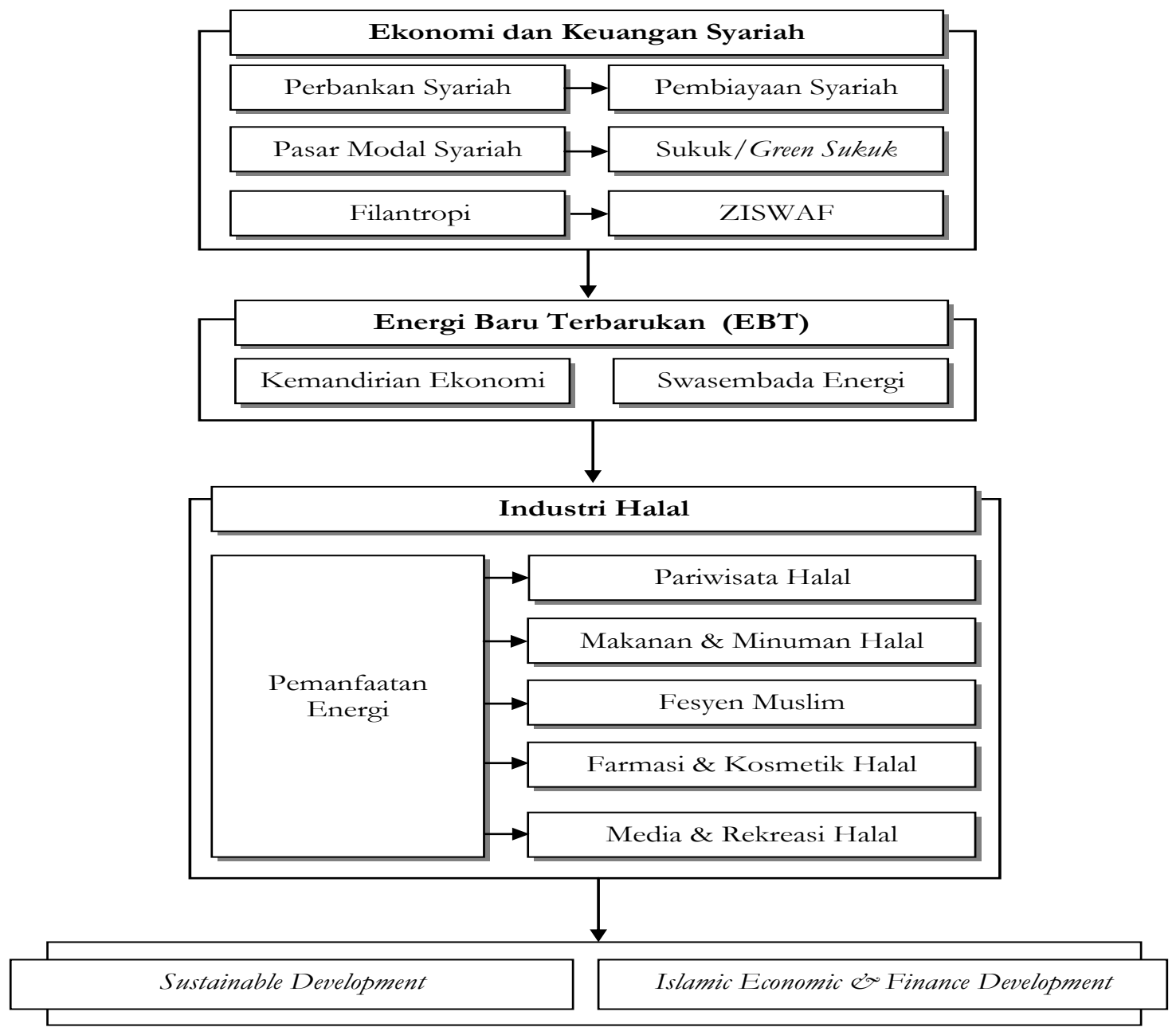

Gambar 1. Skema Sinergitas Energi Terbarukan dan Ekonomi Syariah

39 Kementerian Keuangan, “Ekonomi Hijau Untuk Masa Depan Peradaban.” Majalah Media Keuangan XIV, no. 163 (2021). 
Selain itu, sinergi dengan sektor keuangan syariah dapat dilakukan dengan pengembangan struktur keuangan Islam yang lebih kreatif. Hal itu dapat memanfaatkan aset dasar proyek; meningkatnya jumlah bank syariah dan konvensional yang sekarang bersedia meminjamkan atas dasar keuangan Islami; kesediaan agen ekspor kredit untuk bekerja dengan struktur pembiayaan syariah dan pemberi pinjaman; dan preferensi beberapa sponsor sektor swasta untuk mendapatkan pembiayaan atas dasar keuangan syariah. Alternatif pembiayaan untuk energi terbarukan yang dapat dilakukan melalui lembaga keuangan syariah melalui skema pembiayaan telah pernah dilakukan di lembaga perbankan dengan memberikan pembiayaan solar panel atap. Contohnya, di BPRS Lantabur Tebuireng Jawa Timur. Akad pembiayaan ini digunakan prinsip jual-beli (murābahah). Bank membeli paket produk listrik surya atap, kemudian menjualnya kepada nasabah dengan kesepakatan harga jual ditambah dengan margin penjualan kepada nasabah secara angsuran. ${ }^{40}$

Begitujuga di BNI Syariah, pihaknya melakukan penandatangan akad pembiayaan musyarakah modal kerja dengan PT Medco Power Indonesia sebesar Rp 400 miliar. Pembiayaan modal kerja ini bertujuan untuk corporate financing yang digunakan untuk tambahan modal kerja dan biaya operasional Medco Power. Medco Power Indonesia selama ini dikenal sebagai perusahaan yang unggul di sektor industri listrik terbarukan seperti pembangkit listrik panas bumi, mini hidro dan tenaga surya. Penandatanganan Akad Plafond Pembiayaan ini merupakan wujud dukungan BNI Syariah terhadap program pemerintah Indonesia dalam penggunaan Energi Terbarukan (renewable energy). Dukungan BNI Syariah terhadap penggunaan Energi Terbarukan (renewable energy) ini sesuai amanat Peraturan Otoritas Jasa Keuangan No. 51/POJK.03/2017 tanggal 18 Juli 2017 tentang Penerapan Keuangan Berkelanjutan. PT Medco Power Indonesia, Susilawati Nasution mengatakan saat ini perusahaan sedang membangun proyek energi terbarukan cukup besar di antaranya PLTP Ijen berkapasitas $110 \mathrm{MW}$ yang akan beroperasi penuh (Commercial Operation Date) pada 2023. Selain itu, perusahaan ini juga mempunyai pembangkit Listrik Tenaga Gas dan Uap (PLTGU) di Riau berkapasitas 275 MW. Pada tahun ini, BNI Syariah mengusung tema strategis "Embracing New Opportunities", dimana bank siap meraih peluangpeluang baru dan menjadi partner yang lebih baik bagi seluruh stakeholder salah satunya di bidang energi terbarukan. Hal ini juga sesuai dengan value proposition BNI Syariah yaitu Hasanah Banking Partner, dimana BNI Syariah berkomitmen untuk memajukan ekonomi melalui dukungan kepada Medco Power Indonesia dalam pengembangan Energi Terbarukan di Indonesia. Per Juni 2020, portofolio pembiayaan produktif BNI Syariah mencapai Rp 13,6 triliun. Mayoritas pembiayaan komersial BNI Syariah ini disalurkan ke beberapa sektor industri antara lain konstruksi, listrik, gas air, industri pengolahan, perdagangan, hotel dan restoran, serta jasa dunia usaha. ${ }^{41}$

40 Kementerian Perencanaan Pembangunan Nasional/ Badan Perencanaan Pembangunan Nasional (Bappenas). “Masterplan Ekonomi Syariah Indonesia 2019-2024; Hasil Kajian Analisis Ekonomi Syariah di Indonesia," Cetakan Pertama (2018).

41 Keuangan-Kontan.Co.Id, BNI Syariah salurkan pembiayaan Rp 400 miliar ke Medco Power, https://keuangan.kontan.co.id/news/bni-syariah-salurkan-pembiayaan-rp-400-miliar-ke-medco-power, diakses pada tanggal 4 April 2021. 
Sinergi antara sektor energi terbarukan dengan bidang keuangan syariah lebih lanjut juga telah dilakukan oleh Badan Amil Zakat Nasional (BAZNAS). Lembaga ini berkomitmen untuk mendukung program appropriate mitigation actions in the energi sector (MTRE3). Pada bulan Juli 2017, Rudi Mulyana selaku Dirjen Energi Terbarukan dan Konservasi Kementerian Energi dan Sumber Daya Mineral bersama dengan Zainulbahar Noor selaku Deputi Komisioner BAZNAS menandatangani penyerahan simbolik sumbangan sebesar USD 350,000 dari BAZNAS untuk mendukung program Sustainable Development Goals (SDGs). Pada bulan September lalu BAZNAS baru saja meresmikan Pembangkit Listrik Tenaga Mikro Hidro (PLTMH) di Desa Lubuk Bangkar, Kecamatan Batang Asai, Kabupaten Sarolangun, Provinsi Jambi. Program ini memberikan akses listrik pada 4.448 orang dari 803 rumah tangga. ${ }^{42}$

Hal ini menjadi sasaran yang perlu dicapai bagi sektor energi terbarukan untuk bersinergi dengan sektor keuangan syariah sebagai alternatif sumber pembiayaan dalam mendukung pencapaian target pemenuhan energi terbarukan di Indonesia. Adanya ahli di lembaga keuangan syariah maupun investor lain yang memahami industri energi terbarukan diperlukan untuk menilai risiko investasi sektor energi terbarukan. Tentu dengan nilai capital expenditure yang tinggi, marjin yang tidak besar, dan periode pembiayaan yang cukup panjang. Selanjutnya, dengan optimalnya pemanfaatan EBT di Indonesia, hasil energi tersebut menjadi pendukung untuk ujung tombak industri halal, di antaranya: pariwisata, industri makanan dan minuman, fesyen Muslim, farmasi dan kosmetik, serta media dan rekreasi. Terkhusus pada industri pariwisata halal, Indonesia dapat menyinergikan tempat produksi EBT menjadi salah satu destinasi pariwisata berbasis green tourism. Dengan semakin terintegrasinya kegiatan ekonomi secara global dan kemudahan akses informasi, subsektor pariwisata menjadi salah satu sub-sektor yang mengalami pertumbuhan, baik dalam segi volume transaksi maupun nilai tambah yang dihasilkan. Berdasarkan Global Muslim Travel Index (GMTI) 201943, jumlah wisatawan muslim dunia mencapai 140 juta orang pada tahun 2018 dan diprediksi akan bertambah menjadi 160 juta rang pada tahun 2020 (Grafik 2). Selain itu, Grafik 2 juga menunjukkan bahwa jumlah wisatawan muslim dunia terus mengalami peningkatan setiap tahunnya, sehingga potensi pengembangannya masih sangat besar. Kondisi yang demikian membuat subsektor pariwisata dirasa dapat mendukung pertumbuhan perekonomian di suatu wilayah karena akan mendorong berkembangnya subsector yang lain, misalnya makanan dan minuman, transportasi, dan akomodasi. ${ }^{44}$

42 Kementerian Perencanaan Pembangunan Nasional/ Badan Perencanaan Pembangunan Nasional (Bappenas), “ Masterplan Ekonomi Syariah Indonesia 2019-2024; Hasil Kajian Analisis Ekonomi Syariah di Indonesia", Cetakan Pertama (2018).

43 Crescentrating.com. Global Muslim 2019. https://www.crescentrating.com/reports/global-muslim-travel-index-2019.html, diakses pada tanggal 21 April 2021.

44 PEBS FE UI. Indonesia Sharia Economic Outlook (ISEO) 2020. https://pebsfebui.org/download/indonesia-sharia-economic-outlook-iseo-2020/, diakses pada tanggal 21 April 2021. 


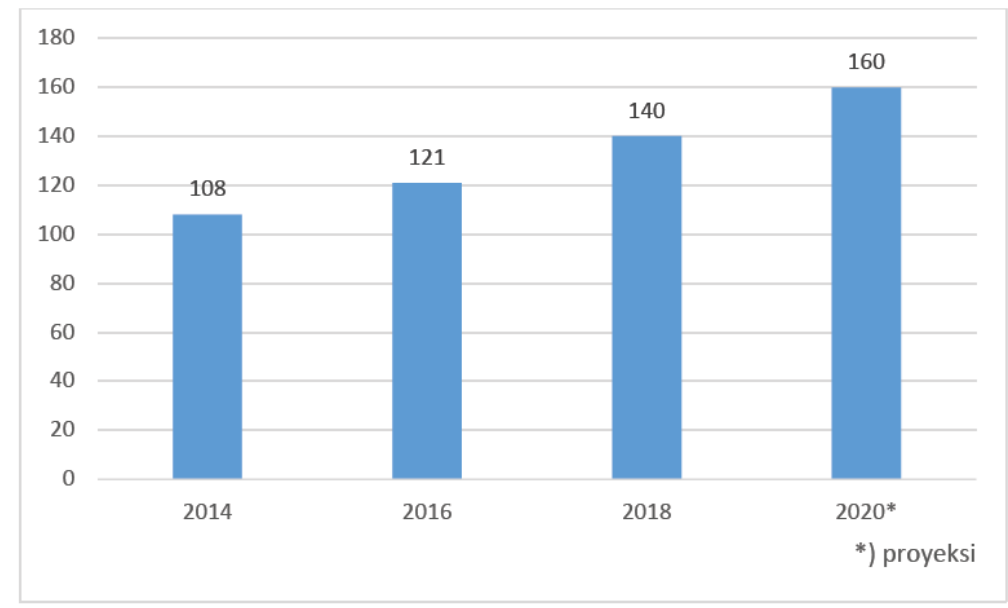

Grafik 2. Jumlah Wisatawan Muslim di Dunia (2014-2020*)

Sumber: Global Muslim Travel Index (GMTI) 2019

Dalam sub-sektor pariwisata halal ini, Indonesia menempati peringkat ke-4 pada Global Islamic Economic Indicator ${ }^{45}$ dengan nilai 52, di bawah Malaysia, UAE, dan Turki masing-masing dengan nilai 95,5; 72,7; dan 72 sebagaimana dapat dilihat pada Grafik 3. Selain itu, pada GMTI 2019, Indonesia bahkan menempati peringkat pertama sebagai daerah wisata halal terbaik, menempati peringkat yang sama dengan Malaysia (Grafik 4). Pada GMTI 2019 juga disebutkan bahwa Indonesia menduduki peringkat teratas dalam berkomunikasi dengan wisatawan Muslim, dimana indikatornya adalah dari segi kemudahan berkomunikasi, digital presence dan jangkauan (outreach). Dalam hal ini, Indonesia mendapatkan nilai tertinggi dalam hal jangkauan (outreach). Selain dalam hal komunikasi, Indonesia juga menjadi negara dengan peringkat teratas dalam hal tingkat pelayanan yang diberikan, di mana Indonesia mendapatkan nilai sempurna pada dua indikator yaitu bandara dan tempat ibadah. ${ }^{46}$

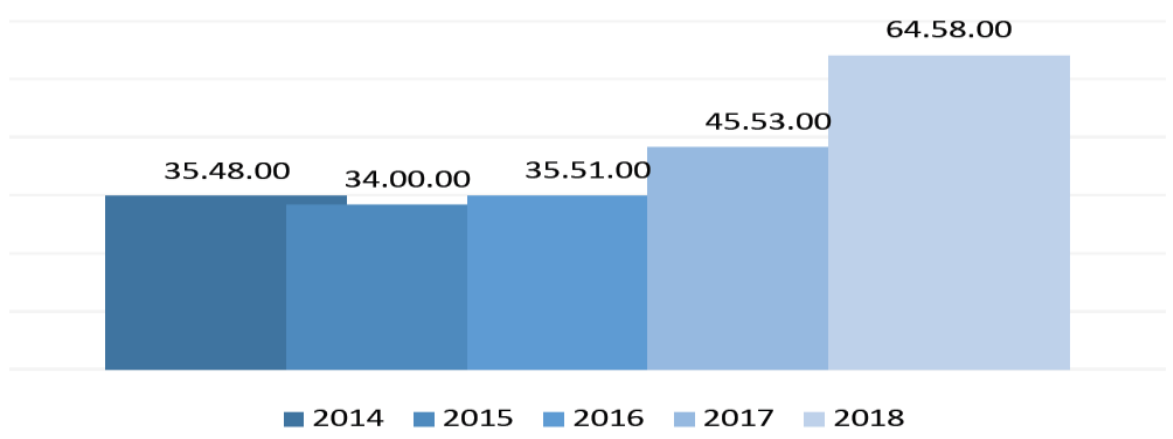

Grafik 3. Peringkat Pariwisata Halal Indonesia

Sumber: State of Global Islamic Economy Report 2018/19

${ }^{45}$ Dubai Islamic Economy Development Centre (DIEDC). State of the Global Islamic Economy Report 2018/19. 는 $\quad$ http:/www.iedcdubai.ae/wp-content/uploads/2019/02/SGIE-Report-201819_Eng_1540649428.pdf, diakses pada tanggal 21 April 2021.

${ }^{46}$ Idem. 


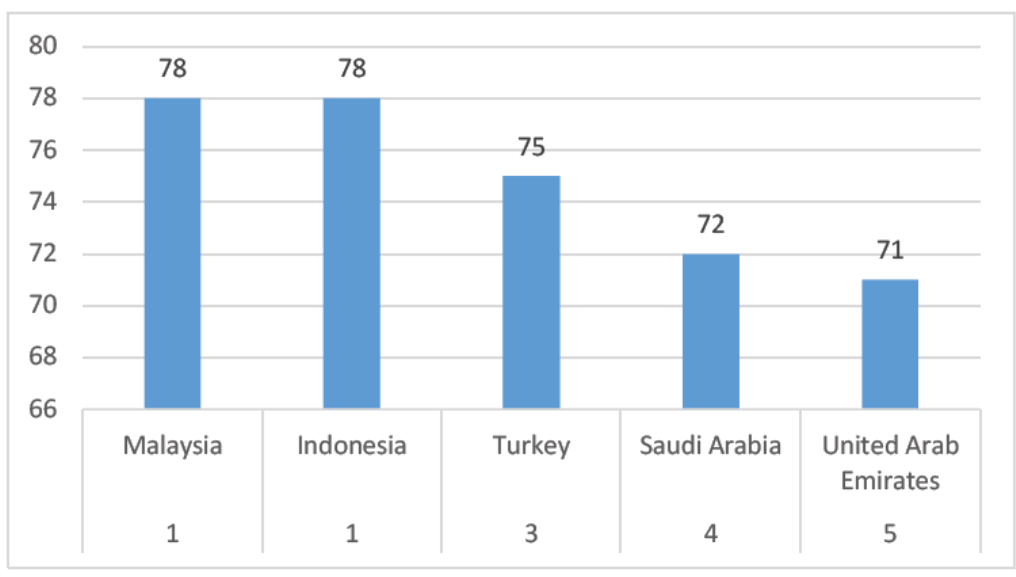

Grafik 4. Perolehan Nilai dan Peringkat Destinasi Wisata Halal Negara OKI

Sumber: Global Muslim Travel Index (GMTI) 2019

Seperti yang telah dipaparkan sebelumnya, salah satu pengguna energi terbesar adalah dari sektor industri. Sinergi pemanfaatan energi terbarukan oleh sektor-sektor yang ada dalam ekosistem industri halal dapat mendukung peningkatan ekonomi yang berkelanjutan secara jangka panjang. Energi terbarukan dapat dimanfaatkan di antaranya oleh industri halal seperti: makanan dan minuman halal, fesyen muslim, pariwisata halal, farmasi dan kosmetik halal dan media dan rekreasi halal. Sebagai contoh, beberapa negara Eropa seperti Jerman dan Inggris telah mengintegrasikan sektor energi terbarukan dengan pariwisata. Hal ini dikenal dengan green tourism. Jerman melalui program Energiewende telah menerapkan integrasi sektor energi terbarukan dengan pariwisatanya. ${ }^{47}$ Walaupun terdapat beberapa pihak yang keberatan dengan adanya program Energiewende, namun selain mampu memberikan energi terbarukan di Jerman, program tersebut mampu meluaskan fungsinya sebagai lokasi pariwisata tanpa menggangu fungsi utamanya untuk menghasilkan energi. Tidak dapat dipungkiri, penambahan fungsi dari sumbersumber energi terbarukan akan meningkatkan kontribusi secara ekonomi di negara tersebut. Model lainnya terdapat di Inggris dengan nama Gladwinsfarm. Tempat wisata ini telah mendapatkan beberapa penghargaan salah satunya dalam kategori green tourism. Pariwisata ramah lingkungan di dalamnya memiliki konsep yang mirip dengan Energiewende. Kebijakan yang diterapkan oleh tempat wisata ini adalah pengurangan carbon footprint, solar tracker panel dan biomass boiler. Kelebihan dari Gladwinsfarm adalah fasilitas yang lebih lengkap sehingga aktivitas yang ditawarkan kepada para pengunjung lebih beragam untuk mempromosikan energi terbarukan dan green tourism.

${ }^{47}$ Clean Energy Wire, Energy transition becomes a tourist attraction, https://www.cleanenergywire.org/news/energy-transition-becomes-touristattraction\#: :text=\%22Tourism\%20and $\% 20$ renewables $\% 20$ are $\% 20$ not, they $\% 20$ can $\% 20$ complement $\% 20$ each \%20other.\%22, diakses pada tanggal 21 April 2021. 
Sinergi EBT dengan industri lain terjadi di Jerman dan Inggris yang telah memanfaatkan EBT untuk industri pariwisatanya. Saat ini hal tersebut belum dilakukan di Indonesia. Berdasarkan potensi yang ada di setiap daerah di Indonesia, salah satu yang dapat disinergikan adalah dengan melihat potensi pengembangan EBT dengan potensi pariwisata halal di setiap wilayah. Di Indonesia, Kementerian Pariwisata telah membuat destinasi wisata halal unggulan. 10 destinasi wisata tersebut meliputi Kepulauan Riau dan Sumatera, Bandung, Jakarta, Yogyakarta, Surabaya, Kepulauan Bali-Nusa Tenggara, Kalimantan, Sulawesi, serta Kepulauan Maluku dan Papua. Salah satu potensi pariwisata halal unggulan di area Great Bali adalah wilayah Nusa Tenggara Barat (NTB). ${ }^{48}$ Wilayah tersebut memiliki potensi energi laut dan tata surya. Potensi energi laut maupun energi tata surya di wilayah tersebut dapat menjadi salah satu potensi sinergi dengan pariwisata berkelanjutan (pariwisata halal) seperti yang sudah dilakukan oleh negara-negara di Eropa. Diperlukan riset dan kolaborasi bersama di antara pihak-pihak pemangku kebijakan serta yang dapat bersinergi antara sektor EBT dengan sektor pariwisata halal tersebut.

Dalam konteks pembiayaan EBT yang bersifat sosial keagamaan, Islam mengajarkan konsep ta'awun, yaitu tolong-menolong, gotong-royong, bantumembantu dengan sesama manusia, seperti perintah Allah pada Surah al-Maidah ayat 2. Dalam hal ini, keuntungan yang diperoleh adalah sedekah jariah yang pahalanya akan mengalir terus. Program ini dapat dilakukan melalui urun dana (crowd funding) untuk memobilisasi potensi wakaf Indonesia sebesar Rp. 60 triliun untuk programprogram sosial sekaligus pemberdayaan masyarakat, khususnya dalam aspek perlindungan lingkungan hidup. Sebagai contoh, wakaf pemasangan solar panel di masjid Salman ITB dan wakaf reaktor biogas telah dilakukan untuk pondok pesantren dan masjid Azzikra di Sentul, Bogor. Pembangunan fasilitas biogas ini tidak hanya untuk energi, namun juga untuk pengolahan limbah cair dari masjid yang sebelumnya di alirkan ke sungai Cikeas yang tentunya ini dilarang syariat Islam karena menimbulkan kemudharatan. Saat ini beberapa skema pembiayaan urun dana melalui wakaf sedang gencar dikembangkan oleh industri perbankan syariah dan Majelis Ulama Indonesia (MUI). ${ }^{49}$

Dalam rangka mengoptimalkan sinergitas antara program energi terbarukan dan ekonomi Syariah, beberapa langkah dan program Quick Wins yang dapat dilakukan adalah:

Pertama, kampanye terhadap keunggulan energi terbarukan untuk mencapai swasembada energi nasional. Salah satu permasalahan di sektor energi terbarukan ialah kurangnya kesadaran atau dukungan serta kepedulian masyarakat terhadap energi terbarukan. Kemudian masyarakat masih sangat bergantung pada energi fosil. Sebanyak 94 persen kebutuhan masih tergantung pada energi fosil. Semua kebutuhan

48 Kementerian Perencanaan Pembangunan Nasional/ Badan Perencanaan Pembangunan Nasional (Bappenas), “Masterplan Ekonomi Syariah Indonesia 2019-2024; Hasil Kajian Analisis Ekonomi Syariah di Indonesia", Cetakan Pertama (2018).

${ }^{49}$ MUI-LPLHSDA, Pembangunan dan Pembiayaan Syariah Energi Baru Dan Terbarukan Untuk Rumah Ibadah, https://mui-lplhsda.org/pembangunan-dan-pembiayaan-syariah-energi-baru-dan-terbarukanuntuk-rumah-ibadah/, diakses pada tanggal 4 April 2021. 
energi yang belum efisien dipenuhi energi fosil tersebut dan malah disubsidi pula. Hal yang dapat dilakukan untuk mengatasi permasalahan ini adalah dengan berkampanye atau menyosialisasikan keunggulan energi terbarukan dibandingkan dengan fosil, serta peningkatan kesadaran masyarakat akan potensi energi terbarukan ini dalam mencapai swasembada energi. Hal ini juga sejalan dengan strategi utama pada kerangka masterplan pengembangan ekonomi Syariah di Indonesia sebagai pusat ekonomi syariah dunia yaitu kampanye nasional gaya hidup halal.

Kedua, terciptanya kemudahan akses dan skema pembiayaan yang menarik untuk mendukung energi terbarukan. Masalah lain yang dihadapi oleh sektor energi terbarukan ialah sulitnya mendapatkan investasi dan pembiayaan untuk proyek pembangunanya. Sektor ini membutuhkan dana yang cukup besar. Hal ini sangat berkaitan dengan persepsi serta pemahaman masyarakat tentang energi terbarukan itu sendiri yang masih rendah. Persepsi mereka masih belum terlalu peduli dan sadar akan lingkungan ditambah dengan pemahaman masyarakat yang masih rendah tentang energi terbarukan. Hal ini menyebabkan masyarakat berpikir bahwa energi terbarukan merupakan bisnis yang tidak menguntungkan, sehingga proyek ini sulit mendapatkan pembiayaan. Pembiayaan syariah dapat menjadi salah opsi pembiayaan proyek energi terbarukan. Banyak instrumen keuangan syariah yang berpotensi untuk mendukung energi terbarukan, dari pembiayaan perbankan syariah, pasar modal syariah, sampai instrumen Zakat, Infak, Sedekah, dan Wakaf (ZISWAF). Hal ini juga sejalan dengan strategi utama dalam masterplan yaitu mendorong pendirian national halal fund..$^{50}$ Oleh karena itulah dibutuhkan skema pembiayaan syariah yang menarik sekaligus dukungan pemerintah dalam berbentuk insentif untuk mendukung proyek energi terbarukan secara finansial.

Ketiga, mengadakan riset dan publikasi mengenai energi terbarukan dan potensi kolaborasi dengan industri lain dalam rantai nilai halal yang dapat diapliksikan di Indonesia, terutama pariwisata halal. Riset dan inovasi sangat dibutuhkan dalam sektor energi terbarukan. Sumber energi dapat berasal dari berbagai macam. Sebagai contoh sudah ada pembangkit listrik yang berasal dari sampah dan kotoran hewan di Amerika Serikat. Hal ini sangatlah bermanfaat di satu sisi untuk mengurangi sampah dan kotoran dan menggunakanya sebagai sumber energi. Di Indonesia juga sudah ada beberapa penelitian mengenai sumber energi terbarukan dari cangkang kakao. Selain dari penelitian mengenai energi terbarukan itu sendiri, dibutuhkan juga riset mengenai potensi kolaborasi antara sektor energi terbarukan dengan sektor lain. Sebagai contoh, berbagai negara Eropa seperti di Jerman dan Inggris telah mengintegrasikan sektor energi terbarukan yang lebih dikenal sebagai green tourism. Jerman melalui program Energiewende (meski ada yang keberatan dengan program tersebut) dan Inggris melalui Gladwinsfarm nya, menambahkan fungsi dari sumber energi terbarukan tersebut sehingga meningkatkan kontribusi ekonomi. Hal ini juga sangat mungkin untuk direalisasikan di Indonesia, sehingga selain energi terbarukan dimanfaatkan sebagai sumber energi untuk

50 Kementerian Perencanaan Pembangunan Nasional/ Badan Perencanaan Pembangunan Nasional (Bappenas), “Masterplan Ekonomi Syariah Indonesia 2019-2024; Hasil Kajian Analisis Ekonomi Syariah di Indonesia", Cetakan Pertama (2018). 
smendukung industri halal lainya. Hal ini juga sejalan dengan strategi utama dalam mewujudkan Indonesia yang mandiri, makmur, dan madani dengan menjadi pusat ekonomi syariah terkemuka dunia yaitu pendirian halal $h u b^{51}$ untuk penguatan industri halal dalam negeri. Energi terbarukan juga dapat berkolaborasi dengan sektor lain untuk dapat memberi nilai tambahan pada perekonomian secara keseluruhan.

\section{KESIMPULAN}

Dalam rangka untuk mendukung tercapainya visi Indonesia yang mandiri, makmur dan madani dengan menjadi pusat ekonomi dan keuangan Syariah terkemuka dunia, klaster energi terbarukan dapat menjadi katalisator untuk penguatan halal rantai nilai (halal value chains). Kontribusinya terlihat dalam peningkatan kemandirian ekonomi melalui swasembada energi. Skema sinergitas di antara program energi terbarukan dan ekonomi/keuangan Syariah dapat digambarkan sebagai berikut:

Pertama, sektor keuangan Syariah dapat menjadi salah satu solusi bagi permasalahan minimnya ketersediaan instrumen pembiayaan yang sesuai dengan kebutuhan investasi EBT. Melalui berbagai pembiayaan berbasis syariah dengan berbagai skema, ekosistem industri keuangan Syariah dapat berkontribusi menjadi salah satu faktor pendukung pencapaian target EBT yang telah ditetapkan.

Kedua, dengan optimalnya pemanfaatan EBT di Indonesia, hasil energi tersebut menjadi pendukung dan ujung tombak industri halal, di antaranya: makanan dan minuman halal, fesyen muslim, pariwisata halal, farmasi dan kosmetik halal dan media dan rekreasi halal. Terkhusus pada industri pariwisata halal, Indonesia dapat menyinergikan tempat produksi EBT menjadi salah satu destinasi pariwisata berbasis green tourism. Seperti yang telah dipaparkan sebelumnya, salah satu pengguna energi terbesar adalah dari sektor industri. Sinergi pemanfaatan energi terbarukan oleh sektor-sektor yang ada dalam ekosistem industri halal dapat mendukung peningkatan ekonomi yang berkelanjutan secara jangka panjang.

Ketiga, dalam konteks pembiayaan EBT yang bersifat sosial keagamaan, EBT dapat dilakukan dengan konsep ta'āwwun dan sedekaj jariah melalui urun dana (crowd funding) untuk memobilisasi potensi wakaf Indonesia sebesar Rp. 60 triliun untuk program-program sosial sekaligus pemberdayaan masyarakat, khususnya dalam aspek perlindungan lingkungan hidup.

Keempat, dalam rangka mengoptimalkan sinergitas antara program energi terbarukan dan ekonomi Syariah, beberapa langkah dan program Quick Wins yang dapat dilakukan adalah: (1) kampanye terhadap keunggulan energi terbarukan untuk mencapai swasembada energi nasional; (2) menciptakan kemudahan akses dan skema pembiayaan yang menarik untuk mendukung energi terbarukan; (3) mengadakan riset dan publikasi mengenai energi terbarukan dan potensi kolaborasi dengan industri lain

\footnotetext{
${ }^{51}$ Idem.
} 
dalam rantai nilai halal yang dapat diapliksikan di Indonesia, terutama pariwisata halal.

\section{REFERENSI:}

Al-Zarkasyi, B. A. M. (1984). Al-burhan fi 'ulum Al-Qur'an. Kairo: Dar al-Turath.

Azhar, M., \& Satriawan, D. A. (2018). Implementasi Kebijakan Energi Baru dan Energi Terbarukan Dalam Rangka Ketahanan Energi Nasional. Administrative Law and Governance Journal, 1(4), 398-412.

Aziz, R. M. (2020). Penanganan Energi Pada Krisis Ekonomi Akibat Covid-19 Sesuai Agama dan Sains. In Seminar Nasional Teknologi Industri Hijau (Vol. 2, No. 1, pp. 194-204).

BP.PLC. (2021). Statistical Review of World Energy 2019, https://www.bp.com/en/global/corporate/energy-economics/statistical-review-ofworld-energy.html. Diakses pada tanggal 31 Maret 2021.

Clean Energy Wire. (2014). Energy transition becomes a tourist attraction, https://www.cleanenergywire.org/news/energy-transition-becomes-touristattraction\#: : :text=\%22Tourism\%20and\%20renewables\%20are\%20not,they\%20can \%20complement\%20each\%20other.\%22, diakses pada tanggal 21 April 2021.

Crescentrating.com. Global Muslim $\quad$ Travel Index 2019. https://www.crescentrating.com/reports/global-muslim-travel-index-2019.html, diakses pada tanggal 21 April 2021.

Creswell, John W. (2012) . Research Design: Pendekatan Kualitatif, Kuantitatif dan Mixed, terj. Achmad Fawaid. Yogyakarta: Pustaka Pelajar.

Dubai Islamic Economy Development Centre (DIEDC). (2018). State of the Global Islamic Economy Report 2018/19. http://www.iedcdubai.ae/wpcontent/uploads/2019/02/SGIE-Report-2018-19 Eng 1540649428.pdf, diakses pada tanggal 21 April 2021.

Eri Hariyanto, E. (2021). Green Financing, Sukuk Negara Dan Pembangunan Berkelanjutan, https://www.djppr.kemenkeu.go.id/page/load/2269/green-financing-sukuknegara-dan-pembangunan-berkelanjutan, diakses pada tanggal 21 April 2021.

Fauzia, I. Y. (2016). Urgensi Implementasi Green Economy Perspektif Pendekatan Dharuriyah Dalam Maqashid Al-Sharia. Jurnal Ekonomi dan Bisnis Islam 2 (1), 87104.

Hamdi, M., Ismaryati, S. (2019). Materi Pokok Metodologi Penelitian Administrasi; 1-12; MAPU5103/4 SKS. Tangerang Selatan: Universitas Terbuka.

Haryanto, S. (2017). Pendekatan Historis Dalam Studi Islam. Manarul Qur'an: Jurnal Ilmiah Studi Islam 17 (1), 127-135.

Ibn Hayyan, M. (1993). Tafsir al-bahr al-muhit. Beirut: Dar al-Kutub al-`Ilmiyyat. 
Iskandar, A., Aqbar, K. (2019). Green Economy Indonesia Dalam Perspektif Maqashid Syari'ah. Al-Mashrafiyah: Jurnal Ekonomi, Keuangan, dan Perbankan Syariah 3 (2), 8394.

Jaelani, A. (2015). Public financial management in Indonesia: Review of Islamic public finance. MPRA Paper, 72340 .

Jaelani, A. (2017). Kebijakan Energi Baru Terbarukan di Indonesia: Isyarat Ilmiah AlQur'an dan Implementasinya dalam Ekonomi Islam. MPRA (83314).

Jaelani, A. (2017). Renewable Energi Policy in Indonesia: Scientific signs of the Qur'an and Implementation in Islamic Economic. MPRA Paper, 83314.

Jonathan, S. (2006). Metode penelitian kuantitatif dan kualitatif. Jakarta: Graha Ilmu.

Juwito, A. F., Pramonohadi, S., \& Haryono, T. (2015). Optimalisasi energi terbarukan pada pembangkit tenaga listrik dalam menghadapi desa mandiri energi di Margajaya. Semesta Teknika, 15(1).

Kementerian Keuangan. (2021). Ekonomi Hijau Untuk Masa Depan Peradaban. Majalah Media Keuangan XIV, no. 163.

Kementerian Perencanaan Pembangunan Nasional/ Badan Perencanaan Pembangunan Nasional (Bappenas). (2018). Masterplan Ekonomi Syariah Indonesia 2019-2024; Hasil Kajian Analisis Ekonomi Syariah di Indonesia, Cetakan Pertama.

Keuangan-Kontan.Co.Id. (2021). BNI Syariah salurkan pembiayaan Rp 400 miliar ke Medco Power, https://keuangan.kontan.co.id/news/bni-syariah-salurkan-pembiayaan-rp400-miliar-ke-medco-power. Diakses pada tanggal 4 April 2021.

Makmun, M. (2011). Green Economy: Konsep, Impelentasi dan Peran Kementerian Keuangan. Jurnal Ekonomi dan Pembangunan 19(2), 1-15.

Mardliyah, W., Sunardi, S., \& Agung, L. (2018). Peran Manusia Sebagai Khalifah Allah di Muka Bumi: Perspektif Ekologis dalam Ajaran Islam. Jurnal Penelitian, 12(2), 355-378.

Muhammad, H. S. (1999). Economic Guidelines in the Quran, Vol. 21. International Institute of Islamic Thought (IIIT).

MUI-LPLHSDA. (2021). Pembangunan dan Pembiayaan Syariah Energi Baru Dan Terbarukan Untuk Rumah Ibadah https://mui-lplhsda.org/pembangunan-danpembiayaan-syariah-energi-baru-dan-terbarukan-untuk-rumah-ibadah/. Diakses pada tanggal 4 April 2021.

Ngada.Org. (2017). Database Peraturan. https://ngada.org/ps222017.htm\#: :text=1.Rencana\%20Umum\%20Energi\%20Nasional,mencapai\%20sasa ran\%20Kebijakan\%20Energi\%20Nasional, diakses pada tanggal 21 April 2021.

PEBS FE UI. (2020). Indonesia Sharia Economic Outlook (ISEO) 2020. https://pebsfebui.org/download/indonesia-sharia-economic-outlook-iseo-2020/, diakses pada tanggal 21 April 2021. 
Peraturan Otoritas Jasa Keuangan No. 51/POJK.03/2017 tanggal 18 Juli 2017 tentang Penerapan Keuangan Berkelanjutan.

Ramli, S., Murad, S. Z. A., Husin, A. F. H. (2014). Biodiesel in holy Quran: among the review of the Arabic lexicography and modern science. Mediterranean Journal of Social Sciences 5(19), 336-336.

Schreier, Margrit. (2012). Qualitative content analysis in practice. Sage publications.

Suprayogi, M. (2016). Jurnal Energi 2. Jakarta: Kementerian ESDM.

The International Renewable Energy Agency (IRENA). (2016). Renewable Energy Outlook For ASEAN", https://www.irena.org/Imedia/Files/IRENA/Agency/Publication/2016/IRENA REmap ASEAN 2016 re port.pdf. Diakses pada tanggal 31 Maret 2021.

UNEP. (2011). Environmental Management Accounting Procedures \& Principles. Newyork.

Vaghefi, N., Siwar, C., dan Aziz, S. A. A. G. (2015). Green economy: issues, approach and challenges in muslim countries. Theoretical Economics Letters 5(1), 28. 